\title{
Buyer-seller conflict and cooperation in marketing channels: port wine distribution
}

\author{
This article was published in the following Dove Press journal: \\ International Journal of Wine Research \\ 4 April 2013 \\ Number of times this article has been viewed
}

\author{
José Crespo de Carvalho \\ Luís Sequeira \\ Lisbon University Institute, Lisboa, \\ Portugal
}

Correspondence: José Crespo

de Carvalho

Lisbon University Institute,

Av das Forças Armadas,

|649-026 Lisboa, Portugal

Tel +35I 938457900

Email crespo.carvalho@gmail.com;

crespo.carvalho@iscte.pt

\begin{abstract}
The main purpose of this study is to research buyer-seller conflict and cooperation in distribution channels. Based on a multidimensional case study, eight research hypotheses were formulated. Some quantitative research was conducted, based on a questionnaire sent to 101 port wine producers and distribution companies (61 answered properly - 31 producers and 29 distributors - which gave the authors a $60 \%$ rate of response, considered to be very good for these types of studies; those 101 port wine producers and distributors initially chosen were the most important in Europe, considering the volume of production and sales, and constituting, for that reason, a convenience sample). A binary probit model was developed to analyze the data. The results of the study demonstrate that when conflict is ongoing and intense it prevents the development of cooperative relationships. A trustworthy company is more likely to solve conflicts. When trust and adaptation capabilities increase, so does potential cooperation. The results also show that the presence of a foreign sales representative in the team does not exert a negative influence on cooperation. Finally, cooperation can be considered as an important means of developing skills and resources, which can then be applied to existing transaction relationships.
\end{abstract}

Keywords: conflict, cooperation, marketing, distribution, multiple channels, port wine

\section{Introduction}

Marketing channels have changed dramatically over the last few decades, particularly in respect of architecture, partnerships, operational practice, and performance skills. ${ }^{1,2}$ There has also been a profound change in the way companies deal with each other. It is possible to observe two trends simultaneously: a deterioration in marketing channel relationships and a closer relationship between some suppliers and buyers. ${ }^{3}$ The high level of coordination required by modern markets has led to a reduction in the number of business partners, with the consequence that collaboration between buyer and supplier has become more intense. ${ }^{4}$

As companies become involved in a more restrictive set of relationships that have a long-term perspective, a new paradigm, based on relationship development and management, has arisen, namely relationship marketing. ${ }^{5-16}$

The development of cooperative relationships constitutes a substantial challenge, not only because of its complexity but also because of the scarcity of time and resources. It is therefore necessary to learn more about these complex relationships. ${ }^{17}$ Although several researchers have focused on buyer-seller cooperation, a number of fundamental questions remain unanswered:

- Why is cooperation so important in principle but so difficult to translate into practice? submit your manuscript $\mid$ www.dovepress.com

Dovepress

http://dx.doi.org/10.2147/IJWR.S43152 
- Is cooperation between distribution partners an important objective?

- Taking into consideration the time and resources required for cooperation, could it lead to an opportunity cost that jeopardizes other relationships?

- Would it be better to develop further collaboration in transaction relationships, rather than to develop cooperation? In the next section we present a summary of the theoretical perspectives of each construct, as well as the resulting hypotheses. The research methodology was focused on a positivistic approach, with questionnaires and statistical treatment. Several hypotheses are proposed, based on the literature reviewed, and are then described, followed by the results of the study and some conclusions.

\section{Theoretical background and hypotheses}

The theoretical model is presented in Figure 1. Cooperation underlies the various relationships. We propose that cooperation is a function of several behavioral constructs: cooperation $=\mathrm{f}$ (supply chain management, power, conflict, trust, interdependence, adaptation, culture, opportunism).

\section{Supply chain management}

Handfield and Nichols ${ }^{18}$ define supply chain management as the integration of all activities associated with the flow and transformation of goods, from raw materials to the final consumer, as well as information flows. Supply chain management is both a logistic and a marketing concept. ${ }^{19,20}$

The perspective is that the supply chain constitutes a system of interdependent companies, which promotes more collaborative relationships and partnerships between buyers and sellers, ${ }^{21-23}$ reducing costs and enhancing relationship quality. ${ }^{24-26}$

The importance of the supply chain has been proved conclusively, not only as a means of improving cost-efficiency but also as a competitive advantage..$^{27,28}$ The chain is therefore considered as a strategic resource. ${ }^{29}$ Supply chain management requires coordination and the integration of activities in key processes ${ }^{30,31}$ through strong formal and informal communication between chain members ${ }^{32}$ and across complex networks of interdependent companies.

Through collaboration within the supply chain, the parties can achieve substantial operational advantages, thus promoting consistent collaboration instead of confrontation. ${ }^{31-38}$ This adds value to products and services and simultaneously develops capacities for solving logistical issues and marketing problems. ${ }^{31}$ Considering that cooperation seems to be facilitated when companies have supply chain management capacities, ${ }^{39-41}$ and taking into consideration Ketchen and Hult's ${ }^{29}$ proposition regarding supply chain management as a competitive advantage, we

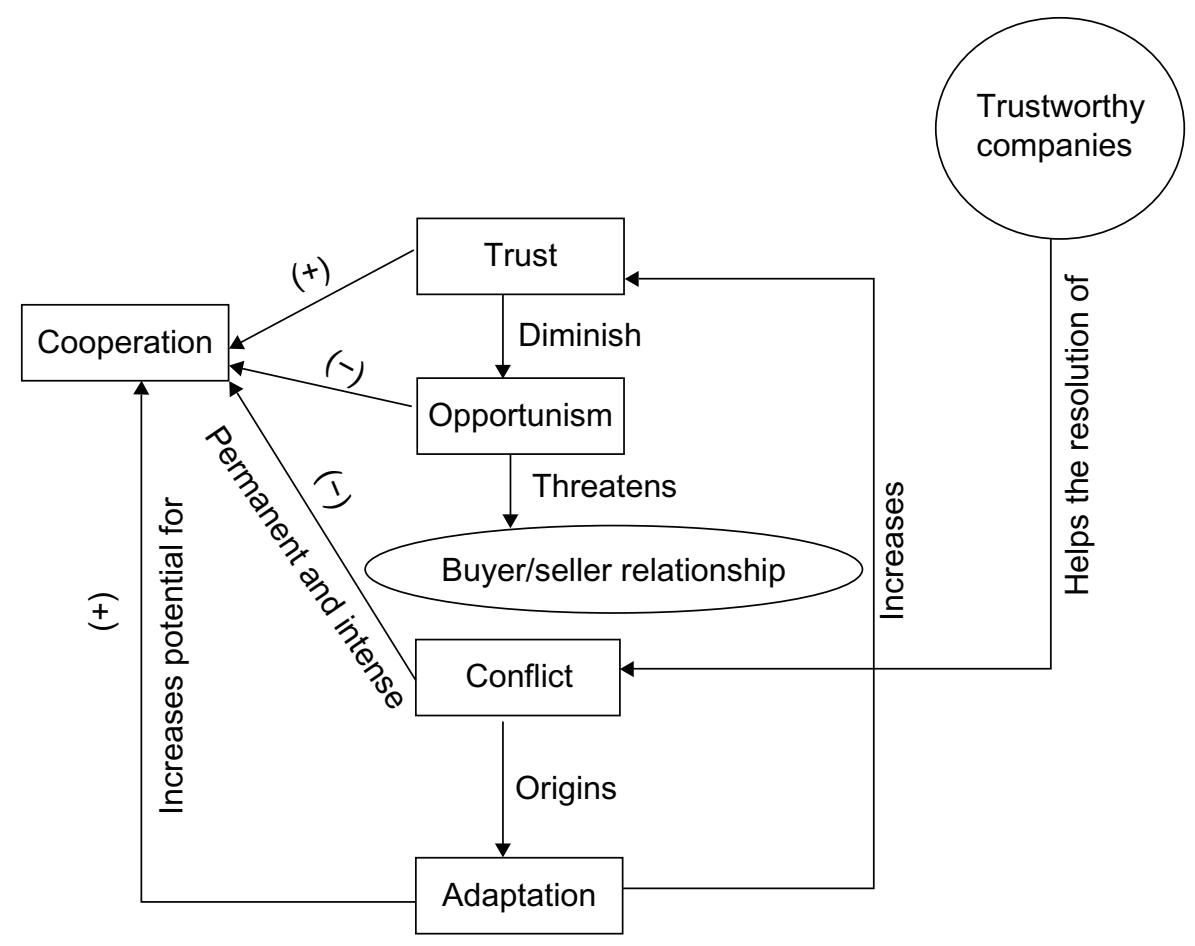

Figure I The theoretical model. 
hypothesize that supply chain management capabilities promote cooperation.

\section{Power}

The construct of power has been researched extensively in the marketing literature. ${ }^{42-53}$ These research efforts are fully justified, given the presence of power in all business relationships. ${ }^{54}$

El-Ansary and Stern's ${ }^{42}$ research was one of the first attempts in the marketing literature to specify the determinants of power. The authors ${ }^{42}$ defined the power of a channel member as his "ability to control the decision variables in the marketing strategy of another member in a given channel at a different level of distribution. For this control to qualify as power, it should be different from the influenced member's original level of control over his own marketing strategy."

Considering the conflict potential in each and every relationship, the manner in which power is used is fundamental to the management of conflict. ${ }^{2}$

Several researchers have come to the conclusion that the use of coercive power in marketing channels damages the relationship, increases conflict, and diminishes trust. ${ }^{2,5,17,43,44,55-57}$

Geylani et a $1^{58}$ observe that a powerful distributor uses coercive power in order to bargain down prices and to obtain more favorable deals from a supplier. The objective is to price the supplier's products lower than the competitor's, but this entails a concomitant increase in conflict. In fact, the use of coercive power seems to be a regular practice in marketing channels. ${ }^{59}$ The most powerful actors can use their power coercively, in order to achieve their objectives. Therefore, we hypothesize that the use of coercive power exerts a negative impact on cooperation.

\section{Conflict}

Gaski $^{45}$ defines conflict as "the perception on the part of a channel member that its goal attainment is being impeded by another, with stress or tension the result." Several authors argue that business relationships always entail conflict and cooperation. ${ }^{60-63} \mathrm{~A}$ high level of conflict is not just a problem in the context of low collaboration. ${ }^{62}$ If not managed appropriately, conflict can lead to the termination of a relationship, but when disputes are managed in the right manner and amicably they can be labeled as functional conflict. ${ }^{64}$ This promotes commitment for both partners, ${ }^{63}$ which is necessary for a sound relationship. ${ }^{65}$

In respect of marketing channels, conflict can also increase when multiple channel strategies are used. ${ }^{66-68}$
Cespedes and Corey ${ }^{69}$ conclude that the use of a multiple channel strategy enables the determination of the degree of conflict to be managed.

Tsay and Agrawal ${ }^{70}$ observe that conflict in marketing channels could undermine attempts to develop cooperative relationships, leading to lower profits for both partners. Hence, we hypothesize that when persistent and intense, competition constitutes an obstacle to cooperation.

\section{Trust}

In the marketing literature, there is extensive research involving behavioral constructs. Trust has been identified as a key element in any business relationship ${ }^{71}$ and is particularly important in any cooperation research, ${ }^{72-74}$ all the more so in the context of marketing channels. ${ }^{75}$

Kumar $^{76}$ defines trust as the "ability of the parties to make a leap of faith: they believe that each is interested in the other's welfare and that neither will act without first considering the action's impact on the other."

Such relationships are time-consuming. Trust cannot be regarded as a static concept. It is something that is in constant evolution. In time, partners get to know each other better and trust levels change as previous successes and failures, as well as general interactions between partners, occur. ${ }^{62,77}$ Trust has been researched not only as a coordination mechanism but also as an important precondition for better performance in complex competitive environments. ${ }^{78}$

Trust has been cited as an essential element for cooperation. ${ }^{19,79,80}$ In fact, cooperation requires a high degree of commitment, and therefore trust is often presented as a basic element of a cooperation relationship. ${ }^{19,79-81}$ Ganesan $^{80}$ states that sellers who are concerned with the success of a retailer, along with their own success, will be trusted to a greater extent than sellers who are interested solely in their own welfare.

Trust is a psychological condition that could be either the cause or the result of cooperation. ${ }^{82,83}$ Perhaps for this reason Spekman and Carraway ${ }^{84}$ argue that despite being a key link in cooperative relationships, trust is fragile and subject to several tensions and vicissitudes. Cooperation is impossible without a minimal level of trust. ${ }^{4}$ The greater the capacity to trust, the lower the transaction costs needed for partners to negotiate, reach agreements, and conduct a cooperation relationship. Trust therefore reduces the need to have legal structures and safeguards to manage the relationship. ${ }^{85,86}$

Therefore, we hypothesize that the greater the level of trust, the greater the propensity to cooperate. 


\section{Interdependence}

No company is self-sufficient. In fact, companies operate within an integrated system of buyers and suppliers. Generally, companies involve themselves in interorganizational transactions in order to achieve the objectives they cannot fulfil through an independent course. As this situation develops further, companies became dependent upon such transactions. ${ }^{87}$ Interdependence exists "whenever one actor does not entirely control all the conditions necessary for the achievement of an action or for obtaining the outcome desired from the action." ${ }^{18}$ Given that the supply of valued resources is limited and that competition for their use is intense, it is inevitable that trade partners providing important resources are difficult to replace. ${ }^{89}$ Within marketing channels, both actors are, to some degree, dependent on each other. The structure of this reciprocal dependence characterizes their interdependence, ${ }^{90}$ given their complementary necessities. ${ }^{91}$ Gattorna ${ }^{92}$ and Bruggen et $\mathrm{a}^{13}$ conclude that the quality of relationships in marketing channels enhances once interdependence increases.

The development of interdependence may constitute a means of mitigating an increase in buyer power. Interdependent relationships create potential (relationship) termination costs, which encourage greater investment in increasing the longterm trust level. ${ }^{94}$ Buyer-supplier interdependence could lead to higher profitability for both partners, as interdependence implies the need and desire to establish mutually beneficial relationships. ${ }^{92,93,95}$ Bruggen et $\mathrm{a}^{93}$ confirm these results, concluding that buyer-seller relationship quality is enhanced when interdependence is increased.

Studying various different buyer-seller relationships, Duffy ${ }^{97}$ notes the existence of three different forms: those with (1) limited coordination, (2) high coordination, and (3) partnerships/cooperation. Duffy ${ }^{97}$ emphasizes the interdependent relevance of cooperation relationships. In fact, interdependence is related to cooperation. When it is high, companies are more willing to pursue long-term competitive advantages, therefore promoting cooperation. ${ }^{98}$

Several researchers argue that interdependence promotes trust $^{27,95,99,100}$ and is a key characteristic of cooperation. ${ }^{4}$ Therefore, we hypothesize that increasing interdependence enhances cooperation.

\section{Adaptation}

Brennan and Turnbull ${ }^{101}$ define adaptation as behavioral or structural modifications, at the individual, group, or corporate level, carried out by one organization, and which are initially designed to meet the specific needs of another organization.
Adaptation is not perceived as merely an answer to the market situation but as an efficient way to maintain and develop a valued relationship.

Ling-Yee ${ }^{102}$ notes that adaptation can be an important source of knowledge, thus facilitating positive relationship development. Therefore, adaptation allows companies to change their structure, in attempting to increase their response capabilities toward partners. ${ }^{103}$ This shows commitment and reduces the distance between parties, leading to relationship strengthening. ${ }^{104}$ Adaptation entails a more behavioral approach to business relationships, allowing for the existence of more flexible partnerships. ${ }^{105}$

In markets where buyers and sellers frequently establish and develop lasting relationships, adaptation to the partner is expected to occur. ${ }^{106}$ Nevertheless, there appears to be evidence that sellers adapt more frequently to buyers than otherwise. ${ }^{107}$

Adaptation may occur as a means of developing a partnership need or to improve and strengthen the relationship itself. ${ }^{101}$ Alternatively, it may be the result of a desire to make adjustments in order to achieve mutual benefits for both partners. ${ }^{108}$ Such adaptations are potentially necessary to allow buyers and sellers to establish successful long-term relationships. ${ }^{109}$

In their study of buyer and seller relationships, Fang et $\mathrm{a}^{110}$ conclude that investments in specific adaptations enhance cooperation. The authors also note that these specific adaptations are followed by a joint effort to accommodate changes in the relationship.

The optimization of activities requires coordination through adaptation, ${ }^{23}$ so that adaptations represent a coordinated and cooperative response to change. ${ }^{11}$

For Brennan and Turnbull, ${ }^{112}$ one important characteristic of "partnership" is the willingness of at least one actor to adapt to the needs of the other. Adaptation strengthens the relationship between business partners. ${ }^{113}$ Hence, we present the following hypothesis: the greater the capacity to adapt, the greater the willingness to cooperate.

\section{Culture}

Marketing decisions are influenced by tangible factors such as the firm's resources and capabilities, but also by intangible factors such as national culture. Hofstede ${ }^{114}$ defined national culture as "the collective programming of the mind which distinguishes one group of category of people from another," adding that "the category of people is the nation." It is assumed that thought and behavior are influenced by cultural values. National culture offers fundamental assumptions and 
values, adding an important tool in the context of business relationship behavior. ${ }^{115}$ The internationalization of business relationships has focused more attention on culture, namely on its impact in these relationships. Culture is reflected in management style or in the way cooperation is handled. ${ }^{116}$ Nowadays, it is common to find employees of different cultures and nationalities in companies. However, what does this imply in terms of cooperation? Therefore, we hypothesize that the presence of a foreign sales representative does not constrain cooperation.

\section{Opportunism}

Opportunism is defined by Williamson ${ }^{117}$ as "self-interest seeking with guile." He adds that opportunism can "involve either data distortion or the making of self-disbelieved promises." Williamson ${ }^{117}$ argues that behaviors such as "tough" negotiations or strong disagreement are not opportunistic behaviors. Either party in a business relationship can engage in opportunism, which involves several elements. ${ }^{118}$ These include: (1) the distortion of information, including overt behaviors such as lying, cheating, and stealing, as well as more subtle behaviors such as misrepresenting information by not fully disclosing; and (2) reneging on implicit commitments such as shirking or failing to fulfil promises and obligations.

Williamson ${ }^{119}$ argues that the opportunism concept does not mean that all actors are unreliable, but implies that one should not become naively involved in relationships.

Several researchers suggest that opportunism could be mitigated by creating control mechanisms. ${ }^{119,120}$ Others argue that opportunism hazard is inherent in any business relationship. ${ }^{121,122}$ In cooperative relationships, opportunism is by no means absent and, in fact, constitutes one of the major threats. ${ }^{123}$

Within marketing channels, it might be more efficient for a seller to work with several distributors, but this could increase the potential for opportunism. ${ }^{124}$ Also, buyer opportunism is negatively related with dependence on a supplier and is positively related to supplier control over seller decisions. ${ }^{125}$

The existence of trust between partners allows for opportunism reduction. ${ }^{57}$ Strong relationships are more important as a means of opportunism control than contracts. ${ }^{126}$

Opportunism does not constitute the opposite of trust. For example, technical support could enhance trust but is not a safeguard against opportunism. ${ }^{127}$ Lado et al ${ }^{128}$ conclude that it is feasible to develop cooperation relationships with a minimal level of trust (generalized trust, as defined by the authors), as long as the risk of opportunism is perceived as low.

We thus hypothesize that opportunistic behavior obstructs the development of cooperative relationships.

\section{Research methodology Sample}

Given the specificity of the study, we used a convenience sample, ${ }^{129}$ therefore focusing our research on the port wine industry, and companies were selected intentionally, including both producers and distributors. We used the databases of the Port Wine Producers Association and the Port Wine Institute in order to obtain information about the relevant companies. For distributors we used information from the Portuguese Distribution Companies Association. We identified a total of 101 companies.

\section{Case studies}

We investigated the distribution processes in three different markets (France, the UK, and the Netherlands) of a specific port wine company. Based on these case studies, we formulated the aforementioned eight hypotheses, which were to be tested quantitatively.

\section{Questionnaire}

A questionnaire with both closed and Likert-scale items was sent to the commercial directors of the 101 identified companies. We received 61 valid questionnaires, amounting to $61.4 \%$ of the sample, which can be considered a good response rate. Indeed, Baruch ${ }^{130}$ analyzed the rate of return of 165 research projects and found an average rate of return of $55.6 \%$ (standard deviation $19.7 \%$ ). The same author noted that the rate of return decreased to $36.1 \%$ (standard deviation $13.3 \%$ ) when the analysis took into consideration questionnaires sent to top management. Denison and Mishra ${ }^{131}$ considered a rate of return of $20 \%-30 \%$ as the expected response rate from a questionnaire sent to top management.

\section{Measurement}

The data were subject to statistical treatment. The dependent variable was dichotomized: value 1 cooperated, value 0 did not cooperate. We followed a long tradition in relationship modeling by using binary models, ${ }^{132-140}$ with the aid of a probit model, using EViews software (IHS Global Inc, Irvine, CA). For statistical treatment, it is necessary to take into consideration that the value for cooperation for some of the companies is null and that $\ln \left(P_{i} / 1-P_{i}\right)$ is not defined when $P_{i}$ equals zero ( $P i$ stands for the value of cooperation). Being 
the natural logarithm, it is not possible to use OLS (Ordinary Least Squares). ${ }^{141}$ In accordance with Norton ${ }^{142}$ and $\mathrm{Ai}$ and Norton, ${ }^{139}$ the existence of a strong correlation between the dependent variable and independent variables may obstruct the use of a linear regression model. In order to ensure no multicollinearity between independent variables, in Table 1 we present a correlation matrix of independent variables, in which it is evident that the highest correlation $(0.249)$ is found between the independent variable "adaptation" and the independent variable "trust." Accordingly, it is clear that correlations between the independent variables are low, and there is no multicollinearity problem.

\section{Results and discussion}

After five interactions, it is evident that the results are quite satisfactory, as the model predicts correctly $83.61 \%$ of the observations. Also, good results were achieved for sensitivity $($ Dep $=1)$ and specificity $($ Dep $=0)$ QMS, with Dep being the dependent variable, and QMS being quantitative microsoftware. ${ }^{143}$ The estimated model is less satisfactory for the Dep $=0$ predictions, with $76.19 \%$, and improves on the Dep $=1$, with $85.50 \%$. Overall, the estimated equation is $18.03 \%$ better at predicting responses than the constant probability model. This change represents a $52.38 \%$ improvement over the $65.57 \%$ correct prediction of the default model (see Table 2).

In Table 3, we present probit results, based on the $Z$ statistic $\left(Z=\sum_{j=1}^{k} \beta_{k} X_{k}\right)$. In accordance with McFaden, ${ }^{144}$ the $R^{2}$ value could be considered very good, with values between 0.20 and 0.40 . Our model shows a result of 0.366 , which can be considered as very good (see Table 3 ).

There was almost complete unanimity amongst respondents that supply chain management capabilities are important. In fact, nearly all companies (98\%) considered that supply chain management capabilities constitute a competitive advantage, which confirms the claims of Hunt and Davis, ${ }^{145}$ Koops et al, ${ }^{146}$ and Li et al. ${ }^{41}$
Nevertheless, supply chain management capabilities were not statistically significant in relation to cooperation relationship development. Hence, one can conclude that although unequivocally considered as a competitive advantage, supply chain management capabilities apparently are not significant of cooperation relationship development.

As Spekman et $\mathrm{al}^{147}$ argue, there seem to be differences in the ways buyers and sellers regard cooperation in the supply chain, or, as Kalafatis ${ }^{148}$ points out, collaboration within the supply chain does not necessarily lead to cooperation.

Several researchers conclude that supply chain management capabilities constitute one key element of the development of any form of distribution relationship. ${ }^{23-25,30,34,39}$

As demonstrated, the great majority of respondents consider supply chain management capabilities as a competitive advantage. Indeed, the evolution of buyer-seller relationships demands supply chain management capabilities as a sine qua non for these relationships to be established. One could argue that supply chain management capabilities are considered as essential, but they do not necessarily constitute a key factor for cooperation relationship development. Hence, the hypothesis that supply chain management capabilities promote cooperation was not confirmed.

Ninety-three percent of the respondents stated that the use of coercive power by a distribution partner severely damages the relationship, confirming the findings of Lusch, ${ }^{43}$ Duarte and Davies, ${ }^{5}$ and Leonidou et al. ${ }^{56}$ These results reflect the concentration trend observed in distribution companies, with the creation of powerful structures that exert power, sometimes in a coercive manner. ${ }^{45}$ This seems to confirm the conclusions drawn by several researchers on the use of coercive power by powerful distribution companies as a means of achieving advantages. ${ }^{17,59,149-152}$

Therefore, it seems that coercive power negatively affects the relationship with distribution partners. Nevertheless, the probit model failed to prove the existence of a determinant

Table I Independent variable correlation matrix

\begin{tabular}{|c|c|c|c|c|c|c|c|c|}
\hline & $\mathbf{I}$ & 2 & 3 & 4 & 5 & 6 & 7 & 8 \\
\hline I. Supply chain management & 1 & & & & & & & \\
\hline 2. Trust & 0.036 & I & & & & & & \\
\hline 3. Power & 0.056 & -0.212 & I & & & & & \\
\hline 4. Adaptation & -0.089 & 0.249 & 0.110 & I & & & & \\
\hline 5. Conflict & 0.197 & $0.315^{*}$ & 0.127 & 0.161 & I & & & \\
\hline 6. Interdependence & -0.054 & -0.068 & 0.017 & 0.100 & 0.027 & 1 & & \\
\hline 7. Opportunism & -0.184 & 0.067 & 0.046 & -0.073 & $-0.357^{* *}$ & -0.077 & I & \\
\hline 8. Culture & 0.173 & -0.018 & 0.057 & 0.065 & 0.066 & 0.072 & -0.047 & I \\
\hline
\end{tabular}

Notes: *Correlation is significant at the 0.05 level (2-tailed); **correlation is significant at the 0.01 level (2-tailed). 
Table 2 Sensitivity, specificity and correctness analysis

\begin{tabular}{|c|c|c|c|c|c|c|}
\hline & \multicolumn{3}{|c|}{ Estimated equation } & \multicolumn{3}{|c|}{ Constant probability } \\
\hline & Dep $=0$ & Dep = I & Total & Dep $=0$ & Dep = I & Total \\
\hline$P($ Dep $=1) \leq C$ & 16 & 5 & 21 & 0 & 0 & 0 \\
\hline$P($ Dep $=1)>C$ & 5 & 35 & 40 & 21 & 40 & 61 \\
\hline Total & 21 & 40 & 61 & 21 & 40 & 61 \\
\hline Correct & 16 & 35 & 51 & 0 & 40 & 40 \\
\hline$\%$ correct & 76.19 & 87.50 & 83.61 & 0.00 & 100.00 & 65.57 \\
\hline$\%$ incorrect & 23.81 & 12.50 & 16.39 & 100.00 & 0.00 & 34.43 \\
\hline Total gain & 76.19 & -12.50 & 18.03 & & & \\
\hline Percent gain & 76.19 & NA & 52.38 & & & \\
\hline
\end{tabular}

Abbreviation: C, constant; Dep, dependent variable.

relationship between the use of coercive power and the development of cooperative relationships.

It is possible that the use of coercive power is regarded essentially as an element that damages relationships, as noted by Maloni and Benton. ${ }^{153}$ The result is the promotion of arm's length relationships with low or no collaboration, or, as concluded by Homburg et al, ${ }^{154}$ that the substantial power of a distributor, when coercively used, has a negative impact on the relationship with the seller, thus preventing collaboration, let alone cooperation. Hence, the hypothesis that the use of coercive power exerts a negative impact on cooperation was not confirmed.

Several authors note that conflict is relatively frequent in business relationships. ${ }^{56,60-63,155}$ Our study generally confirms these conclusions, as $76 \%$ of respondents mentioned conflict as a common element of distribution relationships. For more than half the respondents (52\%), conflict weakens the relationship, $30 \%$ stated that conflict diminishes trust, and for $16 \%$ conflict hinders cooperation. Andrews and Tjosvold ${ }^{156}$ and Jehn ${ }^{157}$ conclude that there is a connection between conflict intensity and the quality of a relationship. Rangaswamy and Bruggen, ${ }^{66}$ Sharma and Mehrotra, ${ }^{67}$ Rosenbloom, ${ }^{68}$ and Cespedes and Corey ${ }^{69}$ come to the conclusion that in order for a relationship to become more collaborative, conflict should be diminished. In fact, conflict can seriously undermine efforts at cooperation. ${ }^{70}$

Our probit results confirm that conflict, when ongoing and intense, and emanating from one distribution partner, is negatively related with cooperation relationship development. Therefore, the results confirm the hypothesis that when persistent and intense, competition constitutes an obstacle to cooperation.

Companies seem to positively trust distribution partners. Our probit results suggest that companies indicating higher trust levels with their distribution partners are more likely to pursue cooperation relationship development. These results conform to those of Song et al, ${ }^{158}$ Ring and Van de Ven, ${ }^{72}$ Geyskens et al, ${ }^{73}$ and Smith et al. ${ }^{74}$

Table 3 Probit results

\begin{tabular}{|c|c|c|c|c|}
\hline Variable & Coefficient & Std error & z-statistic & Prob \\
\hline SCM & 0.261809 & 0.374017 & 0.699992 & 0.4839 \\
\hline Power & 0.159572 & 0.411349 & 0.387924 & 0.6981 \\
\hline Trust & 0.886862 & 0.476713 & 1.860370 & 0.0628 \\
\hline Adaptation & 0.931169 & 0.470357 & 1.979706 & 0.0477 \\
\hline Interdependence & -0.050725 & 0.426376 & -0.118968 & 0.9053 \\
\hline Culture & -0.487863 & $0.24654 I$ & -1.978827 & 0.0478 \\
\hline Opportunism & 0.041679 & 0.458453 & 0.090912 & 0.9276 \\
\hline Conflict & -0.860784 & 0.285824 & -3.011588 & 0.0026 \\
\hline C & -1.057506 & 1.977235 & $-0.53484 \mid$ & 0.5928 \\
\hline Mean dependent variable & 0.655738 & SD dependent variable & & 0.479070 \\
\hline Standard error of regression & 0.397698 & Akaike info criterion & & I.II054I \\
\hline Sum squared residual & 8.224532 & Schwarz criterion & & 1.421981 \\
\hline Log likelihood & -24.87150 & Hannan-Quinn criteria & & 1.232597 \\
\hline Restr log likelihood & -39.27316 & Average log likelihood & & -0.407729 \\
\hline LR statistic (8 df) & 28.80332 & McFadden R-squared & & 0.366705 \\
\hline Probability (LR stat) & 0.000343 & & & \\
\hline
\end{tabular}

Notes: Dependent variable: COOPERATION. Method: ML - binary probit (Quadratic hill climbing). Sample (adjusted): I 6I. Included observations: 6 I after adjustments. Convergence achieved after 5 iterations. Covariance matrix computed using second derivatives.

Abbreviations: C, Constant; df, degrees of freedom; Info, Information; LR, Likelihood Ratio; Probit, Probit Model; SD, Standard Deviation; Restr, restricted; SCM, supply chain management; Std, Standard. 
In addition to confirming these studies, our results confirm a growing connection between trust and cooperation, with the former, being a key element of cooperation, growing in importance as its level increases. This corresponds to the findings of Inkpen, ${ }^{77}$ Gadde and Håkansson, ${ }^{62}$ and Nevin ${ }^{94}$ that trust tends to increase, evolving through different stages into more profound relationships in which cooperation is facilitated. Hence, the hypothesis that the greater the level of trust, the greater the propensity to cooperate was confirmed.

Only 3\% of respondents claim to have a low level of interdependence regarding distribution partners, which indicates that "no company is an island." ${ }^{\circ 6}$ On the other hand, no company stated that they have a very high level of interdependence, and $26 \%$ indicated having a high level of interdependence. These results probably indicate the existence of dependence asymmetry. ${ }^{76,90,159}$ In these cases, as concluded by Hunt and Nevin, ${ }^{44}$ the less dependent partner may use its position as a source of influence over the more dependent partner. The statistical results of the present study did not prove to be not significant in this respect, so it is worth considering the conclusions drawn by Laaksonen et al. ${ }^{100}$ They argue that the existence of a high level of interdependence, combined with a low level of trust, may result in opportunistic relationships. Therefore, the mere existence of a high level of interdependence is not, in itself, a guarantee of cooperation, so the hypothesis that increasing interdependence enhances cooperation is not confirmed.

Adaptation emerges as an important relationship element, as $87 \%$ of respondents claimed to have adapted to a distribution partner, and only $5 \%$ indicated a low adaptation capacity toward distribution partners. The companies also claimed to have adapted to distribution partners as a result of conflicts, and considered these adaptations as positive. These results are in line with Webb, ${ }^{160}$ Dwyer et al, ${ }^{86}$ and Stern et al. ${ }^{161}$

Lukkari and Parvinen ${ }^{104}$ state that adaptation capacities represent a key element for partnership success, and Madhok $^{63}$ considers that repeated interaction amongst actors strengthens the relationship and improves mutual adaptations. Adaptation is therefore not seen as a mere response to market needs but as a means of maintaining or developing a valuable relationship.

Adaptation demonstrates commitment, ${ }^{162}$ constituting the difference between real and rhetorical partnerships. ${ }^{107}$ Also, as stated by Boddy et a ${ }^{163}$ and Fang et al, ${ }^{110}$ partners involved in a cooperation relationship need to be highly adaptable and have a capacity to mould the company according to change. Therefore, adaptation is the result of a high level of knowledge of the partner, as well as high dedication and commitment.

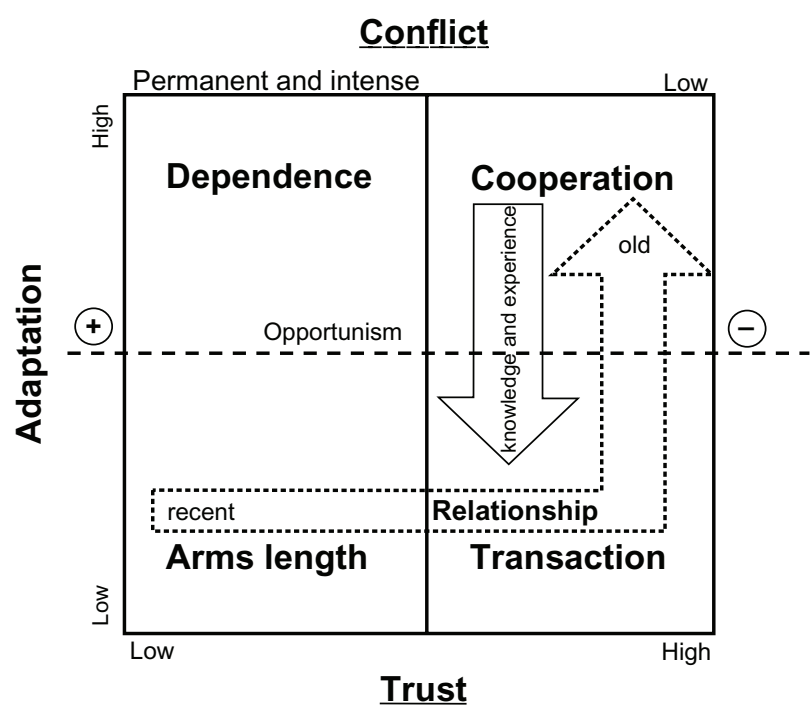

Figure 2 Cooperation matrix.

Hence, the hypothesis that the greater the capacity to adapt, the greater the willingness to cooperate was confirmed.

The probit results show that the presence of a foreign sales representative does not hinder cooperation. Several researchers demonstrate that national culture influences marketing channel relationships. ${ }^{164-166}$ Our case studies yield different results in different countries, indicating that the cultural factor does indeed play an important role. Therefore, the hypothesis that the presence of a foreign sales representative does not constrain cooperation was confirmed.

Seventy-seven percent of the respondents claimed that opportunistic behavior constitutes a threat for relationships, thus confirming the findings of Provan and Skinner, ${ }^{125}$ Eyuboglu et al, ${ }^{87}$ Das,,${ }^{122}$ Morgan and Hunt, ${ }^{64}$ and Berthon et al. ${ }^{98}$ The probit results proved not to be statistically significant. Therefore, despite being considered a threat to relationships, opportunism does not appear to impede the development of cooperation relationships. In fact, opportunism seems to be regarded essentially as a factor that negatively affects buyer-seller relationships, and not as influencing cooperation. It is therefore evident that companies focus mainly on opportunism control or its reduction. Opportunistic behavior does prevent partners from getting to know each other well. One can therefore argue that opportunism constitutes a barrier, preventing relationships from developing further to a more collaborative stage. Hence, the hypothesis that opportunistic behavior obstructs the development of cooperative relationships was not confirmed.

\section{Conclusion}

Based on our results, we present a cooperation matrix in Figure 2. Following our results, we considered three 
constructs affecting cooperation: trust, adaptation, and conflict.

Dependence relationships are characterized by relatively low trust, high adaptation, and ongoing, intense conflict. In these relationships, actors are dependent upon their partner. Adaptations and compromises, often in respect of specific assets, are obtained through intense and continuing conflict underlying relationships with low trust.

In arm's length relationships, actors have low trust in each other and low adaptation capacity, and conflict is intense and permanent. Arm's length relationships are the result of a poor relationship between participants. These relationships constitute a transitory stage. In fact, they cannot be maintained for long, either they develop to a further stage or they will ultimately break down.

Transaction relationships are more frequent. Actors trust each other and conflict is less, but adaptation is low. Several of these relationships are collaborative but not cooperative.

Cooperation relationships are characterized by high trust, high adaptation, and low conflict. The actors generally reach this stage in stable and long relationships. The evolution toward cooperation requires historical knowledge between partners and a sound relationship with controlled conflict and based on adaptation and trust.

Opportunism, as a threat to relationships, is present (with varied intensity) across different relationships. Also, conflict, adaptation, and trust are involved in many different relationships, the difference being the level of intensity.

Relationships evolve as companies get to know each other and adapt to each other. In order to achieve stable and lasting relationships, it is necessary to overcome several barriers, and for that reason time plays an important role.

Not all relationships can, or should, evolve into cooperation, nor can a company develop cooperation in all its relationships. Even if cooperative relationships with distributors constitute a competitive advantage, they should be managed carefully and in a broader corporate context. There is a danger that investing too much in a relationship with some partners may result in a deterioration of others in resources and time demanded by cooperation. These relationships may be a promising research field, with regard to developing cooperative skills for transaction relationships. Sound and productive transaction relationships could be developed as a result of such research. Therefore, cooperation might be considered as an important means of developing skills and resources. Indeed, it might be more productive to prioritize further collaboration in existing transaction relationships, rather than to invest more in cooperative relationships.

\section{Limitations and recommendations for future research}

Our study has focused on buyer-seller relationships in the port wine industry. Therefore, our results can usefully be applied to other sectors. It would be worth studying in greater detail different collaboration alternatives in transactional relationships.

Drawing on our conclusions, an investigation could also be undertaken on the connection between trust and interdependence in cooperative relationships.

Considering multiple channel distribution and the adaptation of sellers to off-trade partners, it would be valuable to research whether or not these adaptations are the result of a voluntary decision or, rather, imposed on off-trade partners. This would shed light on what Heide and John ${ }^{167}$ and Brennan et $\mathrm{al}^{107}$ refer to as overadaptation toward a buyer, creating dependence and a loss of control. In summary, it would be useful to investigate whether adaptations to off-trade partners are the result of a positive buyer impulse or, rather, the result of negative buyer imposition and obligation.

\section{Disclosure}

The authors report no conflicts of interest in this work.

\section{References}

1. Mudambi S, Aggarwal R. Industrial distributors can they survive in the new economy? Industrial Marketing Management. 2003; 32:317-325.

2. Gadde L. Activity coordination and resource combining in distribution networks: implications for relationship involvement and the relationship atmosphere. Journal of Marketing Management. 2004;20:157-184.

3. Frazier G, Antia K. Exchange relationships and interfirm power in channels of distribution. Journal of the Academy of Marketing Science. 1995;23(4):321-326.

4. Ploetner O, Ehret M. From relationships to partnerships: new forms of cooperation between buyer and seller. Industrial Marketing Management. 2006;35(1):4-9.

5. Duarte M, Davies G. Trust as a mediator of channel power. Journal of Marketing Channels. 2004;11(2/3):77-102.

6. Grönroos C. From marketing mix to relationship marketing: towards a paradigm shift in marketing. Management Decision. 1994;32(2):4-20.

7. Sheth J, Parvatiyar A. The evolution of relationship marketing. International Business Review. 1995;4(4):397-418.

8. Gummesson E. Making relationship marketing operational. International Journal of Service Industry Management. 1994;5(5):5-20.

9. Aijo T. The theoretical and philosophical underpinnings of relationship marketing. environmental factors behind the changing marketing paradigm. European Journal of Marketing. 1996;30(2):8-18.

10. Kozak R, Cohen D. Distributor-supplier partnering relationships: a case in trust. Journal of Business Research. 1997;39:33-38.

11. Parvatiyar A, Sheth J. The domain and conceptual foundations of relationship marketing. Handbook of relationship marketing. Parvatiyar A, Sheth J, editors. Thousand Oaks, CA: Sage Publications; 2000:3-38. 
12. Möller K, Halinen A. Relationship marketing theory: its roots and direction. Journal of Marketing Management. 2000;16:29-54.

13. Hunt S. Competing through relationships: grounding relationship marketing in resource-advantage theory. Journal of Marketing Management. 1997;13:431-445.

14. Egan J, Harker M. Relationship marketing: shaking the foundations - the origins of relationship marketing. Thousand Oaks, CA: Sage Publications; 2004.

15. Mattsson L. Relationship marketing and the markets-as-networks approach: a comparative analysis of two evolving streams of research. Journal of Marketing Management. 1997;13:447-461.

16. Robicheaux R, Coleman J. The structure of marketing channel relationships. Journal of the Academy of Marketing Science. 1995;23(4): 38-51.

17. Frazier G, Rody R. The use of influence strategies in interfirm relationships in industrial product channels. Journal of Marketing. 1991;55(January):52-69.

18. Handfield R, Nichols E. Introduction to supply chain management. Upper Saddle River, NJ: Prentice-Hall; 1999.

19. Min S, Mentzer J. The role of marketing in supply chain management. International Journal of Physical Distribution and Logistics. 2000; 30(9):765-787.

20. Rogers D, Leuschner R. Supply chain management: retrospective and prospective. Journal of Marketing Theory and Practice. 2004;12(Fall): 60-65.

21. Bantham J, Celuch K, Kasouf C. A perspective of partnerships based on interdependence and dialectical theory. Journal of Business Research. 2003;56:265-274

22. Hagel III J, Brown J. Productive friction: how difficult business partnerships can accelerate innovation. Harvard Business Review. 2005;83(2): 83-91.

23. Jahre M, Fabbe-Costes N. Adaptation and adaptability in logistics networks. International Journal of Logistics: Research and Application. 2005;8(2):143-157.

24. Liker J, Choi T. Building deep supplier relationships. Harvard Business Review. 2004;82(12):104-113.

25. Omta S, Trienekens J, Beers G. A research and management agenda for chain and network science. Journal on Chain and Newtwork Science. 2002;2(1):1-5.

26. Lambert D, Cooper M. Issues in supply chain management. Industrial Marketing Management. 2000;29:65-83.

27. Mentzer J, Flint D, Hult T. Logistics service quality as a segmentcustomized process. Journal of Marketing. 2001;65(October): 82-104.

28. Slone R. Leading a supply chain turnaround. Harvard Business Review. 2004;82(10):114-121.

29. Ketchen D, Hult T. Toward greater integration of insights from organization theory and supply chain management. Journal of Operations Management. 2007;25:455-458.

30. Stock J, Lambert D. Strategic logistics management. 4th ed. New York, NY: McGraw-Hill; 2001.

31. Alvarado U, Kotzab H. Supply chain management: the integration of logistics in marketing. Industrial Marketing Management. 2001;30: 183-198.

32. McAdam R, McCormack D. Integrating business processes for global alignment and supply chain management. Business Process Management Journal. 2001;7(2):113-130.

33. Duffy R, Fearne A. Partnerships and alliances in UK supermarket supply networks. Food supply chain management. Bourlakis M, Weightman P, editors. Oxford, UK: Blackwell Publishing; 2004:36-152.

34. Christopher M. Logistics and supply chain management. Upper Saddle River, NJ: Prentice-Hall Financial Times; 2012.

35. ECR Europe. The essential guide to day-to-day category management. ECR Europe; 1997.

36. Bhutta K, Huq F, Haubourguet F. Efficient consumer response: increasing efficiency through cooperation. Cahier de Recherche. 2003;1(December):23-32.
37. Dupre K, Gruen T. The use of category management practices to obtain a sustainable competitive advantage in the fast-movingconsumer-goods industry. Journal of Business and Industrial Marketing. 2004;19(7):444-459.

38. Lindblom A, Olkkonen R. An analysis of suppliers' roles in category management collaboration. Journal of Retailing and Consumer Services. 2008;15(1):1-8.

39. Hoyt J, Huq F. From arms-length to collaborative relationships in the supply chain. An evolutionary process. International Journal of Physical Distribution and Logistics Management. 2000;30(9):750-764.

40. Erevelles S, Stevenson T. Enhancing the business-to-business supply chain: insights from partitioning the supply-side. Industrial Marketing Management. 2006;35:481-492.

41. Li S, Ragu-Nathan B, Ragu-Nathan T, Rao S. The impact of supply chain management practices on competitive advantage and organizational performance. Omega. 2006;34:107-124.

42. El-Ansary A, Stern L. Power measurement in the distribution channel. Journal of Marketing Research. 1972;9(February):47-52.

43. Lusch R. Sources of power: their impact on intrachannel conflict. Journal of Marketing Research. 1976;13(November):382-390.

44. Hunt S, Nevin J. Power in a Channel of distribution: sources and consequences. Journal of Marketing Research. 1974;11(May):186-193.

45. Gaski J. The theory of power and conflict in channels of distribution. Journal of Marketing. 1984;48(Summer):9-29.

46. Gaski J. Distribution channels: a validation study. International Journal of Physical Distribution and Logistics Management. 1996;26(5): 64-93.

47. Messinger $\mathrm{P}$, Narasimhan $\mathrm{C}$. Has power shifted in the grocery channel? Marketing Science. 1995;14(2):189-223.

48. Ailawadi K, Borin N, Farris P. Market power and performance: a crossindustry analysis of manufacturers and retailers. Journal of Retailing. 1995;71(3):211-248.

49. Bloom P, Perry V. Retailer power and supplier welfare: the case of Wal-Mart. Journal of Retailing. 2001;77:379-396.

50. Robson I, Rawnsley V. Co-operation or coercion? Supplier networks and relationship in UK food industry. Supply Chain Management: An International Journal. 2001;6(1):39-48.

51. Kim S, Staelin S. Manufacturer allowances and retailer pass-through rates in a competitive environment. Marketing Science. 1999;18(1): 59-76.

52. Farris P, Ailawadi K. Retail power: monster or mouse? Journal of Retailing. 1992;68(4):351-369.

53. Merlo O, Whitwell G, Lukas B. Power and marketing. Journal of Strategic Marketing. 2004;12(December):207-218.

54. Hingley M. Power imbalance in UK agri-food supply channels: learning to live with the supermarkets? Journal of Marketing Management. 2005;21:63-88.

55. Thach E, Olsen J. Building strategic partnerships in wine marketing: implications for wine distribution. Journal of Food Products Marketing. 2006;12(3):71-86.

56. Leonidou L, Talias M, Leonidou C. Exercised power as a driver of trust and commitment in cross-border industrial buyer-seller relationships. Industrial Marketing Management. 2008;37:92-103.

57. Bunduchi R. Trust, power and transaction costs in B2B exchanges: a socio-economic approach. Industrial Marketing Management. 2008; 37:610-622.

58. Geylani T, Dukes A, Srinivasan K. Strategic manufacturer response to a dominant retailer. Marketing Science. 2007;26(2):164-178.

59. Kiyak T, Roath A, Schatzel K. An examination of the coercive power-satisfaction relationship within a relational exchange: the moderating role of dealer resistance. Journal of Marketing Channels. 2001;8(3/4):3-27.

60. Welch C, Wilkinson I. Network perspectives on interfirm conflict: reassessing a critical case in international business. Journal of Business Research. 2005;58:205-213.

61. Stern L, Reve T. Distribution channels as political economies: a framework for comparative analysis. Journal of Marketing. 1980; 44:52-64. 
62. Gadde L, Håkansson H. Supply network strategies. Winchester, PA: John Wiley \& Sons; 2001.

63. Madhok A. Opportunism and trust in joint venture relationships: an exploratory study and a model. Scandinavian Journal of Management. 1995;11(1):57-74.

64. Morgan R, Hunt S. The commitment-trust theory of relationship marketing. Journal of Marketing. 1994;58(July):20-38.

65. Håkansson H, Snehota I. Developing relationships in business networks. London, UK: Routledge; 1995.

66. Rangaswamy A, Bruggen G. Opportunities and challenges in multichannel marketing: an introduction to the special issue. Journal of Interactive Marketing. 2005;19(2):5-11.

67. Sharma A, Mehrotra A. Choosing an optimal channel mix in multichannel environments. Industrial Marketing Management. 2007; 36(1):21-28.

68. Rosenbloom B. Multi-channel strategy in business-to-business markets: prospects and problems. Industrial Marketing Management. 2007; 36(1):4-9.

69. Cespedes F, Corey R. Managing multiple channels. Business Horizons. 1990;(July-August):67-77.

70. Tsay A, Agrawal N. Channel conflict and coordination in the e-commerce age. Production and Operations Management. 2004;13(1):93-110.

71. Arnott D. Trust: current thinking and future research. European Journal of Marketing. 2007;41(9/10):981-987.

72. Ring P, Van de Ven A. Developmental processes of cooperative interorganizational relationships. Academy of Management Review. 1994;19(1):90-118.

73. Geyskens I, Steenkamp J, Scheer L, Kumar N. The effects of trust and interdependence on relationship commitment: a trans-Atlantic study International Journal of Research in Marketing. 1996;13:303-317.

74. Smith K, Carroll S, Ashford S. Intra- and interorganizational cooperation: towards a research agenda. Academy of Management Journal. 1995;38(1):7-23.

75. Halliday S. Which trust and when? Conceptualizing trust in business relationships based on context and contigency. International Review of Retail, Distribution and Consumer Research. 2003;13(4): 405-421.

76. Kumar N. The power of trust in manufacturer-retailer relationships. Harvard Business Review. 1996;74(November-December):92-106.

77. Inkpen A. Strategic alliances. Handbook of strategic management. Hitt M, Freeman F, Harrison J, editors. Malden, MA: Blackwell Publishing; 2005:409-432.

78. Free C. Walking the talk? Supply chain accounting and trust among UK supermarkets and suppliers. Accounting, Organizations and Society. 2008;33(6):629-662.

79. Lui S, Ngo H, Hon A. Coercive strategy in interfirm cooperation: mediating roles of interpersonal and interorganizational trust. Journal of Business Research. 2006;59:466-474.

80. Ganesan S. Determinants of long-term orientation in buyer-seller relationships. Journal of Marketing. 1994;58(April):1-19.

81. Johnston D, McCutcheon D, Stuart I, Kerwood H. Effects of supplier trust on performance of cooperative supplier relationships. Journal of Operations Management. 2004;22:23-38.

82. Rousseau D, Sitkin S, Burt R, Camerer C. Not so different after all: a cross-discipline view of trust. Academy of Management Review. 1998;23(3):393-404.

83. Blomqvist K. The many faces of trust. Scandinavian Journal of Management. 1997;13(3):271-286.

84. Spekman R, Carraway R. Making the transition to collaborative buyerseller relationships: an emerging framework. Industrial Marketing Management. 2006;35(1):10-19.

85. Ring P, Van de Ven A. Structuring cooperative relationships between organizations. Strategic Management Journal. 1992;13:483-498.

86. Dwyer R, Schurr P, Oh S. Developing buyer-seller relationships. Journal of Marketing. 1987;51(April):11-27.

87. Eyuboglu N, Ryu S, Tellefsen T. Current and future interdependence: effects on channel relationships. Journal of Marketing Channels. 2003;11(1):3-26.
88. Pfeffer J, Salincik G. The external control of organizations: a resource dependence perspective. Stanford, CA: Stanford University Press; 1978.

89. Buchanan L. Vertical trade relationships: the role of dependence and symmetry in attaining organizational goals. Journal of Marketing Research. 1992;29(February):65-75.

90. Gundlach G, Cadotte E. Exchange interdependence and interfirm interaction: research in a simulated channel setting. Journal of Marketing Research. 1994;31(November):516-532.

91. Luo Y. Structuring interorganizational cooperation: the role of economic integration in strategic alliances. Strategic Management Journal. 2008;29:617-637.

92. Gattorna J. Devoloping a channels strategy. Handbook of logistic and distribution management. Gattorna J, editor. Aldershot, UK: Gower Publishing; 1999:90-101.

93. Bruggen G, Kacker M, Nieuwlaat C. The impact of channel function performance on buyer-seller relationships in marketing channels. International Journal of Research in Marketing. 2005;22: 141-158.

94. Nevin J. Relationship marketing and distribution channels: exploring fundamental issues. Journal of the Academy of Marketing Science. 1995;23(4):327-334.

95. Shaw S, Gibbs J. Retailer-supplier relationships and the evolution of marketing: two food industry case studies. International Journal of Retail and Distribution Management. 1995;23(7):7-16.

96. Peppers D, Rogers M. Managing customer relationships: a strategic framework. 2nd ed. Winchester, PA: John Wiley \& Sons; 2011.

97. Duffy R. Towards a better understanding of partnership attributes: an exploratory analysis of relationship type classification. Industrial Marketing Management. 2008;37:228-244.

98. Berthon P, Pitt L, Ewing M, Bakkeland G. Norms and power in marketing relationships: alternative theories and empirical evidence. Journal of Business Research. 2003;56:699-709.

99. Yilmaz C, Sezen B, Ozdemir O. Joint and interactive effects of trust and (inter) dependence on relational behaviors in long-term channel dyads. Industrial Marketing Management. 2005;34:235-248.

100. Laaksonen T, Pajunen K, Kulmala H. Co-evolution of trust and dependence in customer-supplier relationships. Industrial Marketing Management. 2008;37(8):910-920.

101. Brennan R, Turnbull P. Adaptations in buyer-seller relationships. Network dynamics in international marketing. Naudé P, Turnbull P, editors. Oxford, UK: Pergamon; 1998.

102. Ling-Yee L. The effects of relationship governance mechanisms on relationship performance: how do relationship learning process matter? Journal of Marketing Channels. 2007;14(3):5-30.

103. Levinthal D. Adaptation in rugged landscapes. Management Science. 1997;43(7):934-950.

104. Lukkari P, Parvinen P. Pharmaceutical marketing through the customer portfolio: institutional influence and adaptation. Industrial Marketing Management. 2008;37(8):965-976.

105. Mukherji A, Francis J. Mutual adaptation in buyer-supplier relationships. Journal of Business Research. 2008;61:154-161.

106. Hallén L, Johanson J, Seyed-Mohamed N. Interfirm adaptation in business relationships. Journal of Marketing. 1991;55(April):29-37.

107. Brennan R, Turnbull P, Wilson D. Dyadic adaptation in businessto-business markets. European Journal of Marketing. 2003;37(11/12): $1636-1665$

108. Hagberg-Andersson A. Adaptation through cooperation in a supply network. Proceedings of the 17th IMP Conference: Oslo, Norway; 2001.

109. Canning L, Hanmer-Lloyd S. Building trust and commitment in buyersupplier adaptation process. Proceedings of the 17th IMP Conference: Oslo, Norway; 2001.

110. Fang S, Wu J, Fang S, Chang Y, Chao P. Generating effective interorganizational change: a relational approach. Industrial Marketing Management. 2008;37(8):977-991.

111. Gulati R, Lawrence P, Puranam P. Adaptation in vertical relationships: beyond incentive conflict. Strategic Management Journal. 2005; 26:415-440. 
112. Brennan R, Turnbull P. Sophistry, relevance and technology transfer in management research: an IMP perspective. Journal of Business Research. 2002;55(7):595-602.

113. Johanson J, Mattsson L. Interorganizational relations in industrial systems: a network approach with the transaction cost approach. International Studies of Management and Organization. 1987;17(1): 34- 48 .

114. Hofstede G. Cultural constraints in management theories. Academy of Management Executive. 1993;7(1):81-94.

115. Fang T. Culture as a driving force for interfirm adaptation: a Chinese case. Industrial Marketing Management. 2001;30:51-63.

116. Bearden W, Money B, Nevins J. Multidimensional versus unidimensional measures in assessing national culture values: the Hofstede VSM 94 example. Journal of Business Research. 2006;59: 195-203.

117. Williamson O. Markets and hierarchies: analysis and antitrust implications. A study in the economics of internal organization. London, UK: The Free Press; 1975.

118. Jap S, Anderson E. Safeguarding interorganizational performance and continuity under ex post opportunism. Management Science. 2003; 49(12):1684-1701.

119. Williamson O. Opportunism and its critics. Managerial and Decision Economics. 1993;14(2):97-107.

120. Stump R, Heide J. Controlling supplier opportunism in industrial relationships. Journal of Marketing Research. 1996;33(November): $431-441$.

121. John G. An empirical investigation of some antecedents of opportunism in marketing channel. Journal of Marketing Research. 1984; 21(August):278-289.

122. Jones $\mathrm{G}$. Towards a positive interpretation of transaction cost theory: the central roles of entrepreneurship and trust. Handbook of strategic management. Hitt M, Freeman F, Harrison J, editors. Malden, MA: Blackwell Publishing; 2005:208-228.

123. Das T. Time-span and risk of partner opportunism in strategic alliances. Journal of Managerial Psychology. 2004;19(8):744-759.

124. McAfee P, Schwartz M. Opportunism in multilateral vertical contracting: nondiscrimination, exclusivity, and uniformity. The American Economic Review. 1994;84(1):210-230.

125. Provan K, Skinner S. Interorganizational dependence and control as predictors of opportunism in dealer-supplier relations. Academy of Management Journal. 1989;32(1):202-212.

126. Deeds D, Hill C. An examination of opportunistic action within research alliances: evidence from the biotechnology industry. Journal of Business Venturing. 1998;14:141-163.

127. Sako M, Helper S. Determinants of trust in supplier relations: evidence from the automotive industry in Japan and the United States. Journal of Economic Behavior and Organization. 1998;34:387-417.

128. Lado A, Dant R, Tekleab A. Trust-opportunism paradox, relationalism, and performance in interfirm relationships: evidence from the retail industry. Strategic Management Journal. 2008;29:401-423.

129. Patton M. Qualitative evaluation and research methods. Newbury Park, CA: Sage Publications; 1990.

130. Baruch Y. Response rate in academic studies: a comparative analysis. Human Relations. 1999;52(4):421-438.

131. Denison D, Mishra A. Towards a theory of organizational culture and effectiveness. Organization Science. 1995;6(2):204-223.

132. Bucklin R, Siddarth S, Silva-Risso J. Distribution intensity and new car choice. Journal of Marketing Research. 2008;45(August):473-486.

133. Wang H, Yu Y, Zhang K. Ensemble probit models to predict cross selling of home loans for credit card customers. International Journal of Data Warehousing and Mining. 2008;4(2):1-21.

134. Hoetker G. The use of logit and probit models in strategic management research: critical issues. Strategic Management Journal. 2007; 28:331-343.

135. Jones S, Hensher D. Evaluating the behavioural performance of alternative logit models: an application to corporate takeovers research. Journal of Business Finance and Accounting. 2007;34(7): 1193-1220.
136. Richards T. A nested logit model of strategic promotion. Quantitative Market and Economics. 2007;5:63-91.

137. Coughlan A. Competition and cooperation in marketing channel choice: theory and application. Marketing Science. 1985;4(2):110-129.

138. Heide J, Weiss A. Vendor considerations and switching behavior for buyers in high-technology markets. Journal of Marketing. 1995;59(July):30-43.

139. Ai C, Norton E. Interaction terms in logit and probit models. Economic Letters. 2003;80:123-129.

140. Zidda P, Lockshin L, van der Haert S. Channel choice behaviour for different usage situations: the case of the wine product category. Proceedings of the 4th International Conference of the Academy of Wine Business Research: Siena, Italy; July 17-19, 2008.

141. Aldrich J, Nelson F. Linear probability, logit, and probit models. Thousand Oaks, CA: Sage Publications; 1984.

142. Norton E. Computing interaction effects and standard errors in logit and probit models. The Stata Journal. 2004;4(2):154-167.

143. QMS. EViews 5 user's guide. Editions Quantitative Micro Software LLC; 2004.

144. McFaden D. The theory and practice of disaggregate demand forecasting for various modes of urban transportation. Berkeley, CA: University of California, Institute of Transportations Studies; 1976.

145. Hunt S, Davis D. Grounding supply chain management in resourceadvantage theory. Journal of Supply Chain Management. 2008; 44(1):10-21.

146. Koops S, Mollenkopf D, Zwart T. Food supply chains: are efficiency and responsiveness mutually exclusive? Journal on Chain and Network Science. 2002;2(1):7-17.

147. Spekman R, Kaufman J, Myhr N. An empirical investigation into supply chain management. A perspective on partnerships. International Journal of Physical Distribution and Logistics Management. 1998; 28(8):630-650.

148. Kalafatis S. Buyer-seller relationships along channels of distribution. Industrial Marketing Management. 2000;31:215-228.

149. Kumar N. Marketing as strategy: understanding the CEO's agenda for driving growth and innovation. Boston, MA: Harvard Business School Press; 2004.

150. Chen M, Chang H, Huang C, Liao C. Channel coordination and transaction cost: a game-theoretic analysis. Industrial Marketing Management. 2006;35:178-190.

151. Hingley M, Hollingsworth A. Competitiveness and power relationships: where now for the UK food supply chain? Working paper. Proceedings of the 19th Annual IMP Conference: Lugano, Switzerland; 2003.

152. Benton W, Maloni M. The influence of power driven buyer/seller relationships on supply chain satisfaction. Journal of Operations Management. 2005;23:1-22.

153. Maloni M, Benton W. Power influences in the supply chain. Journal of Business Logistics. 2000;21(1):49-73.

154. Homburg C, Schneider J, Fassnacht M. Opposites attract, but similarity works: a study of interorganizational similarity in marketing channels. Journal of Business-to-Business Marketing. 2002;10(1): 31-54.

155. Anderson J, Narus J. A model of distributor firm and manufacturer firm working partnerships. Journal of Marketing. 1990;54(July):42-58.

156. Andrews R, Tjosvold D. Conflict management under different levels of conflict intensity. Journal of Occupational Behavior. 1983;4(3): 223-228.

157. Jehn K. A qualitative analysis of conflict types and dimensions in organizational groups. Administrative Science Quarterly. 1997;42: 530-557.

158. Song M, Di Benedetto A, Zhao Y. The antecedents and consequences of manufacturer-distributor cooperation: an empirical test in the US and Japan. Journal of the Academy of Marketing Science. 2008;36: 215-233.

159. Geyskens I, Steenkamp J, Kumar N. Generalizations about trust in marketing channel relationships using meta-analysis. International Journal of Marketing Research. 1998;15:223-248. 
160. Webb K. Managing channels of distribution in the age of electronic commerce. Industrial Marketing Management. 2002;31:95-102.

161. Stern L, El-Ansary A, Coughlan A. Marketing channels. Upper Saddle River, NJ: Prentice-Hall; 1996.

162. Hagberg-Andersson A. Does adaptation pay off? Industrial Marketing Management. 2006;35:202-209.

163. Boddy D, Macbeth D, Wagner B. Implementing collaboration between organizations: an empirical study of supply chain partnering. Journal of Management Studies. 2000;37(7):1003-1017.

164. LaBahan D, Harich K. Cross-national channel relationship performance: the role of cultural sensitivity, conflict and communication. Working paper. California State University-Fullerton; 1994.
165. Kale S, Barnes J. Understanding the domain of cross-national buyer-seller interactions. Journal of International Business Studies. 1992;23(1):101-132.

166. Griffith D, Hu M, Ryans J. Process standardization across intra and inter-cultural relationships. Journal of International Business Studies. 2000;31(2):303-324.

167. Heide J, John G. Do norms matter in marketing relationships? Journal of Marketing. 1992;56(2):32-44.
International Journal of Wine Research

\section{Publish your work in this journal}

The International Journal of Wine Research is an international, peer-reviewed open-access, online journal focusing on all scientific aspects of wine, including: vine growing; wine elaboration; human interaction with wine; and health aspects of wine. The journal provides an open access platform for the reporting

\section{Dovepress}

of evidence based studies on these topics. The manuscript management system is completely online and includes a very quick and fair peer-review system, which is all easy to use. Visit http://www.dovepress.com/testimonials.php to read real quotes from some of our published authors.

Submit your manuscript here: http://www.dovepress.com/international-journal-of-wine-research-journalisease-journal 